\title{
Long-Branched Structure of Polybutadienes Analyzed by Rheology
}

\author{
Shuichi MAEDA ${ }^{* \dagger}$, Koji SHIBA ${ }^{* *}$, Michinori SUZUKI ${ }^{* *}$ \\ "Advanced Science and Innovational Center, Organization for Research Initiatives, Yamaguchi University, \\ 2-16-1 Tokiwadai, Ube, Yamaguchi 755-8611, Japan \\ ${ }^{* *}$ Polyolefin and Rubber R\&D Dept, Synthetic Rubber Div, Ube Industries, Ltd, \\ 8-1 Goi-minamikaigan, Ichihara, Chiba 290-0045, Japan
}

\begin{abstract}
The linear and nonlinear viscoelastic properties of five polybutadienes (PBs: Y1, Y2, V, Co1, and Co2) synthesized using three different catalysts and two processes were measured to investigate their molecular structures, with a focus on long-branched structures. Concentrated PB solutions $(10 \%, 30 \%, 50 \%)$ were prepared with liquid paraffin as the solvent. The storage modulus $G^{\prime}$ and loss modulus $G^{\prime \prime}$ of the PB solutions and PB melts were measured. The relationships between $G^{\prime} c^{-2}$ and $G^{\prime \prime} c^{-2}$ corrected by concentration $(c)$ are strongly dependent on the presence or absence of long branches in PBs. At $G^{\prime \prime} c^{-2}=20,000 \mathrm{~Pa}$, the value of $G^{\prime} c^{-2}$ for long-branched PBs increases with PB concentration, and also increases for more complex long-branched structures. The values of $G^{\prime} c^{-2}$ for Y2 and V were not dependent on concentration. The results showed that Y2 and V have linear molecular structures and that Y1, Co1, and Co2 have long-branched structures, with the order of complexity being $\mathrm{Y} 1>\mathrm{Co} 1>\mathrm{Co} 2$. From the damping functions evaluated by large-deformation stress relaxation measurements of the $30 \% \mathrm{~PB}$ solutions, the order of long-branched structural complexity was $\mathrm{Y} 1>\mathrm{Co} 1>\mathrm{Co} 2>\mathrm{V} \approx \mathrm{Y} 2$. This order was essentially the same as that based on the linear viscoelasticity of the PB samples. The rheological method in this study provides structural information about long-branched PBs.

Key Words: Polybutadiene / Long-branched structure / Concentrated solution / Linear viscoelastic property / Non-linear viscoelastic property
\end{abstract}

\section{レオロジーによるポリブタジエンの長鎖分岐構造解析}

前田 修一", 斯波 晃司, 鈴木 通典

(原稿受理：2021 年 2 月 19 日)

\section{1. 緒 言}

ポリブタジエン（PB）は，シス体，トランス体，ビニル 体の 3 つの異性体で構成されており, 一般的にシス体の含有 率が多いほど，ゴム特性に優れるといわれている年2).PBの 用途として, 靴底, ゴルフボールなどの一般工業用途, ス ポーツ用途などが挙げられるが, 大部分はタイヤ用途が占め ている ${ }^{3)}$. 一概にタイヤ用途といっても用いられる箇所によ り，要求される特性は異なる，例えば，路面と接地する卜 レッドに関しては耐摩耗性や低発熱性が求められ, 車両の荷 重を支えるサイドウォールに関しては高剛性や耐屈曲亀裂成 長性が必要とされる4). このような特性は, PB 分子中の異性 体の割合や異種 PB の混合様式などに強く依存することが知 られており，主に触媒技術を駆使して，さまざまな $\mathrm{PB}$ が製

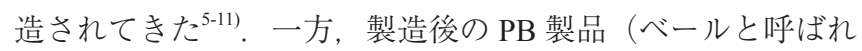
る）のハンドリングや成形加工性には, PBの長鎖分岐構造 が大きく影響されることが指摘されている ${ }^{12,13)}$.さらに，最
近，長鎖分岐末端構造を制御することによりカーボンブラッ クやシリカなどの無機物との相互作用を強化した新規タイヤ 用材料が開発されている ${ }^{14,15)}$. このような PBに対する高度 な要求に応えるために，異性体割合と長鎖分岐構造を同時に 制御するための触媒あるいはプロセスに関する研究開発が盛 んに行われている。特に, 長鎖分岐構造解析に関しては, 従 来, 希薄溶液物性 ${ }^{16}, \mathrm{SEC}^{17)}, \mathrm{NMR}^{18)}$, レオロジー ${ }^{19-28)}$ を用 いる方法が知られている。特に，分子量だけではなく，長鎖 分岐構造まで精緻に制御された試料を用いたレオロジー研究 が行われている26,27).

本研究の目的は, 種々の触媒を用いて, 工業プロセスに近 い手法により重合された分子量分布を有する PBの分子構造, 特に長鎖分岐構造に関する分子構造的特徵を明らかにするこ とである. 3 つの触媒系により重合された $\mathrm{PB}$ 試料の濃厚溶 液と溶融物における一般的な線形粘弾性および非線形粘弾性 測定から PB の長鎖分岐構造の違いについて検討した結果を 述べる。

\footnotetext{
† 山口大学大学研究推進機構先進科学イノベーション研究センター

T755-8611 山口県宇部市常盤台2-16-1

E-mail : maeshu1@yamaguchi-u.ac.jp, Tel : +81-086-85-9944
} 
Table I Molecular characteristics of PBs in this study.

\begin{tabular}{c|rc|ccc}
\hline \multirow{2}{*}{$\begin{array}{c}\text { Sample } \\
\text { code }\end{array}$} & \multirow{2}{*}{$M_{\mathrm{w}} / 10^{4}$} & $M_{\mathrm{w}} / M_{\mathrm{n}}$ & \multicolumn{3}{|c}{ Micro structure/\% } \\
\cline { 4 - 6 } & & & Cis & Trans & Vinyl \\
\hline \hline Y1-7 & 7 & 2.4 & 88.9 & 9.0 & 2.2 \\
Y1-45 & 45 & 3.7 & 91.0 & 6.9 & 2.2 \\
Y1-77 & 77 & 6.2 & 90.6 & 7.3 & 2.1 \\
\hline Y2-43 & 43 & 2.4 & 99.7 & 0.0 & 0.3 \\
\hline V-11 & 11 & 2.3 & 87.4 & 1.4 & 11.2 \\
V-48 & 48 & 2.5 & 87.8 & 0.9 & 11.3 \\
V-102 & 102 & 4.4 & 87.6 & 0.9 & 11.5 \\
\hline Co1-58 & 58 & 3.5 & 98.0 & 0.7 & 1.4 \\
\hline Co2-58 & 58 & 2.6 & 98.6 & 0.4 & 0.9 \\
\hline
\end{tabular}

\section{2. 実 験}

\section{1 試料}

本研究では， $\mathrm{Y}$ 系， $\mathrm{V}$ 系， $\mathrm{Co}$ 系の3つの触媒系を用いて， 重合プロセスなどを変えることにより 5 系列（Y1 系，Y2， $\mathrm{V}$ 系, $\mathrm{Co} 1, \mathrm{Co} 2)$ で分子量の異なる 9 種類の $\mathrm{PB}$ 系試料を 合成した。触媒金属が異なることにより，PBの分岐構造が 異なることが報告されている ${ }^{29,30)}$ ，また，重合プロセスを変 えることにより Y 系およびCo 系の分岐構造を変えた。両触 媒系において，1 1 より分岐構造が多い PB が合成できる. $\mathrm{PB}$ 試料の重量平均分子量 $M_{\mathrm{w}}, M_{\mathrm{w}}$ と数平均分子量 $M_{\mathrm{n}}$ の比 $\left(M_{\mathrm{w}} / M_{\mathrm{n}}\right)$ および 3 種類の異性体の割合を試料コードととも に Table I に示した，異性体の割合は，FT-IR（ATR 法）測定 から評価した。分子量が大きい Y1-77 および V-102の $M_{\mathrm{w}} / M_{\mathrm{n}}$ はそれぞれ 6.2 および 4.4 と大きいが, 他の $\mathrm{PB}$ 試料の $M_{\mathrm{w}} /$ $M_{\mathrm{n}}$ は 2.3〜3.7であった。 また, $\mathrm{Y} 1$ 系, $\mathrm{Y} 2$ 系および $\mathrm{V}$ 系 $\mathrm{PB}$ では，それぞれトランス体，シス体およびビニル体が他の触 媒系 PBより多い特徵がある.

濃厚溶液試料は PB をトルエンに溶解後, 所定の流動パラ フィンを添加し，その後 $60^{\circ} \mathrm{C} ， 8$ 時間以上の真空乾燥によ りトルエンを完全に留去して調製した。各PB系において, それぞれ PB 濃度 $(c)$ が $10 \%, 30 \%, 50 \%$ の 3 種類の濃厚溶 液試料を調製した。

\section{2 測定}

試料の粘弾性特性を測定するために，直径 $25 \mathrm{~mm}$ および $8 \mathrm{~mm}$ のパラレルプレートを装着した TA 社製の ARES を用 いた。溶融体を含めた各種の濃厚溶液試料の貯蔵弾性率 $G^{\prime}$ および損失弾性率 $G^{\prime \prime}$ を, 温度範囲 $0 \sim 100{ }^{\circ} \mathrm{C}$, 角周波数範 囲 $1 \times 10^{2} \sim 1 \times 10^{-2} \mathrm{rad} \mathrm{s}^{-1}$ の条件で線形範囲のひずみを印 加して測定した。 また, 大変形応力緩和測定は $30 \% \mathrm{~PB}$ 濃厚 溶液試料を用いて, 温度 $40{ }^{\circ} \mathrm{C}$, ひずみ範囲 $0.5 \sim 4$ の条件で 行った。

\section{3. 結果および考察}

\section{1 溶媒希釈による PB の見かけの分子構造変化}

まず，長鎖分岐構造および直鎖構造を有する PB を溶媒で 希釈することによる見かけの分子構造変化について考える。

Fig. 1 (A) および $(\mathrm{D})$ に，それぞれ長鎖分岐構造および直鎖構 造を有する PB 分子の溶融状態（PB 濃度 $100 \%$ ）における
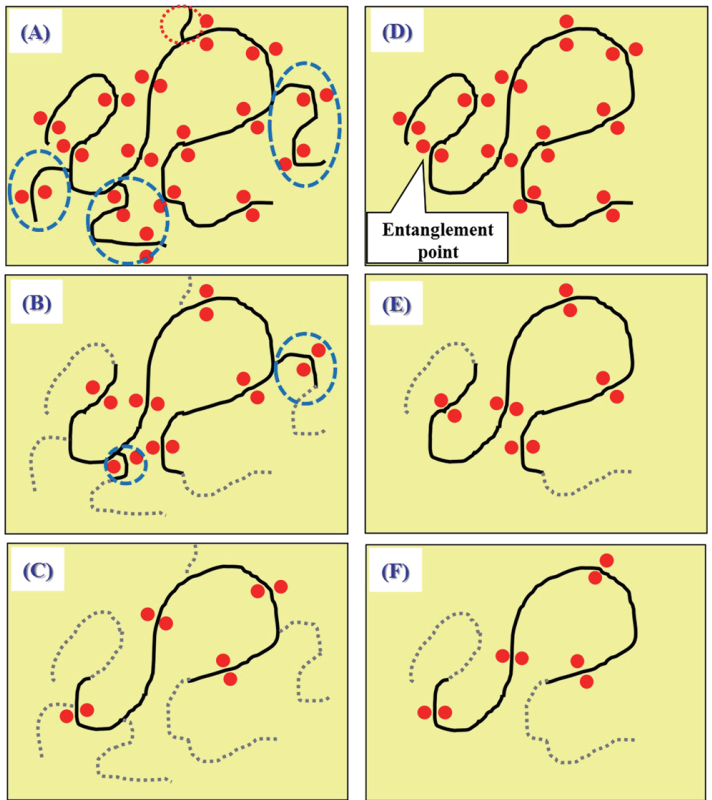

Fig. 1 Schematic diagram of apparent molecular structure changes for longbranched and linear polybutadienes diluted with a solvent. Two closed-circle pairs stand for entanglement points on a PB molecule. Broken lines and dot line surround long-branch and short-branch on a molecule, respectively. The polymer concentrations are as follows; (A) and (D) $>$ (B) and (E) $>$ (C) and (F).

模式図を示した，図中の赤い丸印は他の分子との絡み合い点 を表している。また，Fig. 1(A) 中には，破線および点線に より分岐鎖を囲っている。ここで，破線で囲まれた分岐鎖に は絡み合い点が存在するため, これらは長鎖分岐鎖である. 一方，点線で囲まれた分岐鎖には絡み合い点が存在していな いので，短鎖分岐鎖となる. Fig. 1(A)に示したような長鎖 分岐構造を有するPBに良溶媒を加えることにより，分子中 の絡み合い点間の距離が大きくなる, つまり絡み合い点間分 子量 $\left(M_{\mathrm{e}}\right)$ が大きくなる。ささらに分子末端部が絡み合い系か ら除外される。この様子を Fig. 1(B)に模式的に示した. 図 より $M_{\mathrm{e}}$ は大きくなり, 分子末端部が絡み合い系から外れる ため見かけの分子量が小さくなったように見える。ただし， いくつかの長鎖分岐鎖にはまだ絡み合い点が存在するため, この分子は見かけ長鎖分岐構造のままである。なお，絡み合 い系から外れた末端部を点線で表している。ささらに溶媒を加 えると Fig. 1(C)に示すように, $M_{\mathrm{e}}$ はより大きくなり, 分子 末端部においても絡み合い系から外れる部位が長くなり, こ の分子は見かけ分子量が小さい直鎖構造に変わる。ここで, 見かけの分子構造が長鎖分岐構造から直鎖構造へ変わる溶媒 量は, PBの分子量, 分岐数および分岐鎖長に依存すると考 えるのが妥当であろう。換言すれば，見かけの PB 分子構造 変化の濃度依存性は長鎖分岐構造の違いに依存する。一方,

Fig. 1 (D) に示した直鎖構造を有する PB 分子に良溶媒を加え ると, Fig. 1(E)に示したように $M_{\mathrm{e}}$ が大きくなるとともに分 子末端部が絡み合い系から除外されていく，さらに溶媒を加 えると Fig. 1(F)に示すように， $M_{\mathrm{e}}$ はさらに大きくなり，分 子末端部においても絡み合い系から外れる部位がさらに長く なる。しかし，直鎖構造分子をいくら溶媒で希釈しても Fig. 1(E) および (F)に示すように，この分子は見かけ分子量 は小さくなるが直鎖構造のままで変化しない. 


\section{2 各種 PB の線形粘弾性}

溶媒による希釈による長鎖分岐構造および直鎖構造を有す る分子の見かけの分子構造変化が異なることを記述した．次 に, 見かけの分子構造変化に起因する $\mathrm{PB}$ 試料の線形粘弾性 変化について述べる. Fig. 2 に， $M_{\mathrm{w}}$ がほぼ同程度の V-48 お よびY1-45のそれぞれ 4 種類の PB 濃度の $G^{\prime}$ および $G^{\prime \prime}$ の基 準温度 $40{ }^{\circ} \mathrm{C}$ におけるマスターカーブを示した。 V-48におい て低角周波数領域におけるすべての試料の $G^{\prime \prime}$ は角周波数の 1 乗に比例して低下し, 溶融体をのぞく 3 種類の濃厚溶液試 料における $G^{\prime}$ は角周波数のほぼ 2 乗に比例して低下してお り, すべての濃度試料のマスターカーブはゴム状平坦領域の 一部から流動領域までが観測されていることがわかる。また， PB 濃度に応じて各試料の弾性率は大きく異なるが, $G^{\prime}$ およ び $G^{\prime \prime}$ のマスターカーブの形状は分子量分布があまり狭くな い一般的な直鎖構造の高分子のそれらと同様に見える。一方, Y1-45 においては各試料の $G^{\prime}$ および $G^{\prime \prime}$ のマスターカーブの 形状は PB 濃度により大きく異なる。例えば，溶融体である $100 \%$ 試料では, 測定した角周波数範囲において $G^{\prime}$ は $G^{\prime \prime} よ$ り常に大きいが, 濃度 $10 \%$ 試料では $G^{\prime}$ は $G^{\prime \prime} よ り$ 常に小さ い. なお, 濃度 $10 \%$ 試料の $G^{\prime}$ および $G^{\prime \prime}$ のマスターカーブ の形状はV-48における濃度 $10 \%$ 試料のそれらとよく似た 形状であることもわかる.

高分子濃厚溶液では, 濃度に依存して $M_{\mathrm{e}}$ が変化するだけ でなく, 絡み合い数および絡み合い点における分子間の摩擦 係数が異なり, それらの違いに応じて系の粘弾性挙動が変化 すること ${ }^{29)}$ が知られている．2つの PB 試料系で観察された 濃厚溶液試料における $G^{\prime}$ および $G^{\prime \prime}$ のマスターカーブの形 状および弾性率の違いは PB 試料の分子構造の違いを強く反 映していると考えられる.

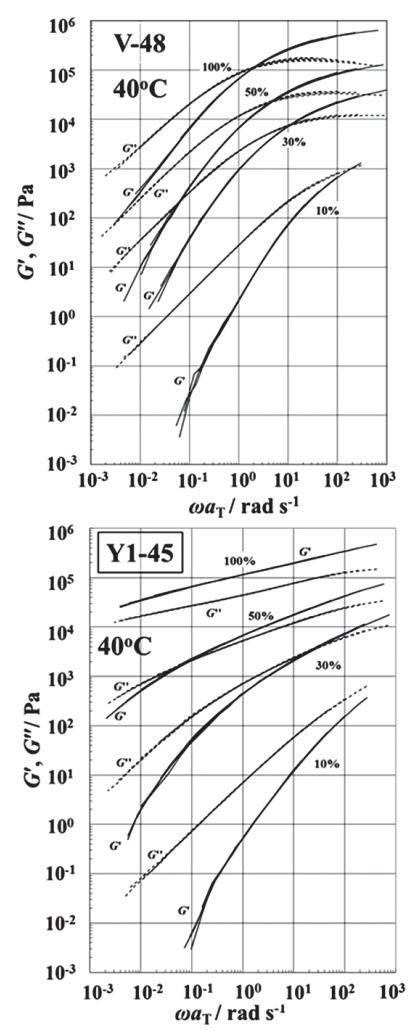

Fig. 2 Master curves of $G^{\prime}$ and $G^{\prime \prime}$ for V-48 and Y1-45 at a reference temperature of $40^{\circ} \mathrm{C}$. PB concentrations for each PB systems are shown in these figures.
まず，濃厚溶液の弾性率に及ぼす濃度と $M_{\mathrm{e}}$ について考え る。三次元架橋ゴムのゴム弾性理論を拡張して, 絡み合い系 のゴム状平坦弾性率 $G_{\mathrm{N}}{ }^{0}$ は式(1)で与えられる ${ }^{31)}$.

$$
G_{N}^{0} \propto \frac{c R T}{M_{e}}
$$

ここで， R はガス定数である。一般的な高分子濃厚溶液に対 しては, $M_{e} \propto c^{-1}$ の関係 ${ }^{31)}$ が知られており, 式(1)より $G_{N}^{0} \propto c^{2}$ の関係が得られる。つまり, 高分子濃厚溶液では高分子濃度 に反比例して $M_{\mathrm{e}}$ は大きくなり， $G_{\mathrm{N}}{ }^{0}$ は $c^{2}$ に比例する関係が 成立する。また，これらの関係は分岐構造の違いに影響され ないと考えられる。 なお, 高分子濃厚溶液のレオロジー挙動 に及ぼす高分子濃度による絡み合い数および絡み合い点にお ける摩擦係数の影響については, 濃厚溶液系の緩和時間の違 いとしてあらわれると考えられる。本研究では高分子濃厚系 の緩和時間に対する濃度に依存した絡み合い数および摩擦係 数の影響を, 各種濃厚系試料の $G^{\prime \prime}$ に対して $G^{\prime}$ を両対数プ ロットする，いわゆるHan プロット ${ }^{32}$ から評価することを 行った. Han プロットでは, 緩和機構が同一の場合, 系の緩 和時間の大小にかかわらず同一の曲線関係が得られ，一方， 緩和機構が異なる場合は $G^{\prime}$ および $G^{\prime \prime}$ から得られる曲線は 異なることが知られている.

$\mathrm{PB}$ 濃厚溶液試料の絡み合い点間分子量および緩和時間の 補正を, 濃度補正後の $G^{\prime} c^{-2}$ と $G^{\prime \prime} c^{-2}$ を用いたHan プロット により行った。 Fig. 3 に，V-48 およびY1-45における $G^{\prime} c^{-2}$ と $G^{\prime \prime} c^{-2}$ の Han プロットを示した。 V-48の Han プロットに おいて，4種類の濃度における曲線が広い弾性率範囲にわ たって良好に重なっていることがわかる。一方，Y1-45にお いては，溶液濃度により4つの曲線が重ならないことがわか る。これらの結果から，V-48 は測定したすべての濃厚溶液 の緩和機構が同一であること，およびY1-45 がすべての試 料の緩和機構が異なることが示唆される。つまり，V-48は 直鎖構造であり溶液希釈により見かけの分子構造は変化しな
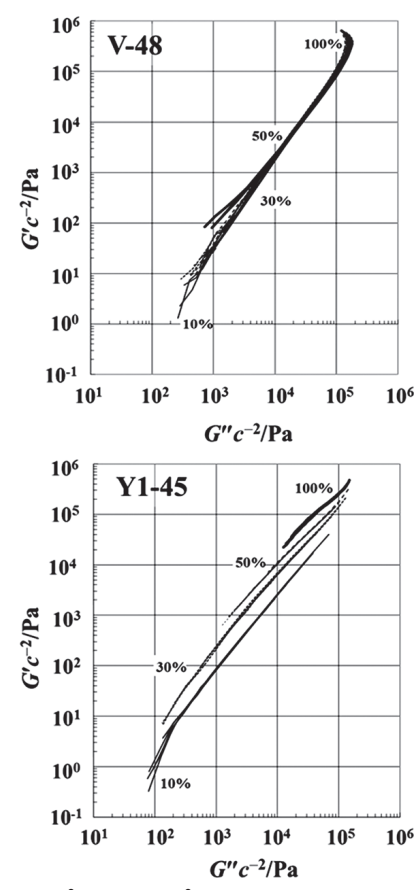

Fig. 3 Han plots of $G^{\prime} c^{-2}$ and $G^{\prime \prime} c^{-2}$ for V-48 and Y1-45, PB concentrations for each $\mathrm{PB}$ systems are shown in these figures. 
いが，Y1-45 は長鎖分岐構造であるため, 見かけの分子構造 は長鎖分岐構造から直鎖構造へと変化したと考えられる.

Fig. 4 に，V系およびY1 系の分子量ならびに濃度が異な るそれぞれ 4 種類の試料における $G^{\prime} c^{-2}$ と $G^{\prime \prime} c^{-2}$ の Han プロッ トを示した，V系の Han プロットにおいて，すべての試料 における曲線が広い弾性率範囲にわたってほぼ重なっている ことがわかる。一方，Y1系においては，すべて曲線が重な らないことがわかる。特に, 分子量が最も小さいY1-7 (100\%) および濃度がともに $30 \%$ である Y1-45（30\%）と Y1-77（30\%）の曲線でさえ重なっていない. これらの結果 から，V系は分子量に係わらずすべての濃厚溶液の緩和機構 が同一であり，V系試料は直鎖分子構造であると考えられる. また，Y1 系試料はすべて長鎖分岐構造であり，分子量が異 なる試料では長鎖分岐の数ならびに長さが異なると推察して いる.

本研究で用いた PB 試料の分子構造の違いを明らかにする ために, Fig. 5 に分子量がほぼ同一である 5 種類の試料につ
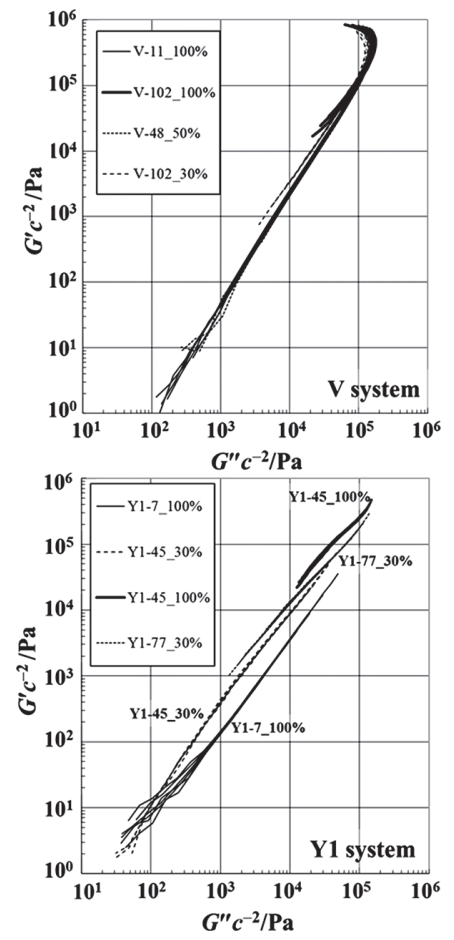

Fig. 4 Han plots of $G^{\prime} c^{-2}$ and $G^{\prime \prime} c^{-2}$ for $\mathrm{V}$ system and $\mathrm{Y} 1$ system with different $\mathrm{PB}$ concentrations are shown in these figures.

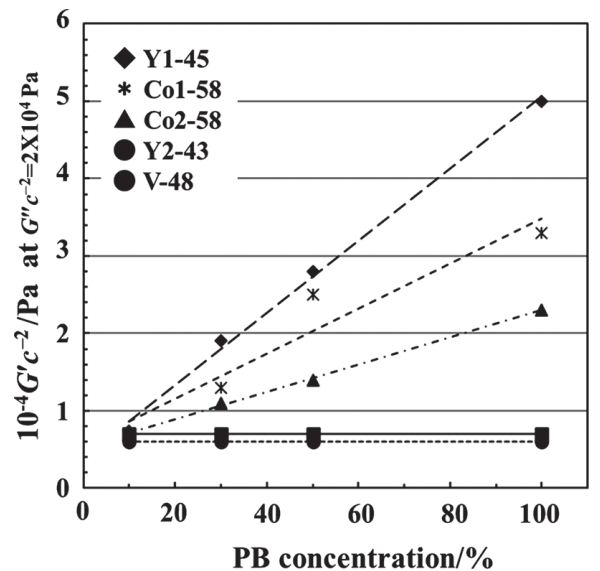

Fig. $5 G^{\prime} c^{-2}$ at $G^{\prime \prime} c^{-2}=20,000$ Pa plotted against PB content for five PB samples.
いて $G^{\prime \prime} c^{-2}$ が 20,000 Paにおける $G^{\prime} c^{-2}$ の值を $\mathrm{PB}$ 濃度に対し てプロットした。ここで, $\mathrm{PB}$ 試料の分子構造の違いを $G^{\prime \prime} c^{-2}$ が 20,000 Pa における $G^{\prime} c^{-2}$ の值で検討した理由としては，す べての試料においてこれらの測定值が得られたためである. 図より，V-48 およびY2-43の $G^{\prime} c^{-2}$ はともに PB 濃度に依存 せずに一定であり，これらは直鎖構造であると考えられる。 一方，Y1-45，Co1-58 およびCo2-58 では，それらの $G^{\prime} c^{-2}$ は $\mathrm{PB}$ 濃度につれて大きくなり，同一のPB 濃度における序列 は，Y1-45>Co1-58>Co2-58であった。これらの結果は, Y1-45，Co1-58 およびCo2-58 は長鎖分岐構造を有すること， 並びに Y1-45 > Co1-58>Co2-58 の序列でそれらの長鎖分岐 構造がより複雑となっていることがうかがえる。

\section{3 各種 PB の非線形粘弾性}

高分子濃厚溶液の線形粘弾性挙動から各種 PB 試料の長鎖 分岐の有無も含めた分子構造の違いについて検討してきた. 次に非線形粘弾性特性から PB 試料の分子構造について検討 を行う。

長鎖分岐構造を有する系も含む多くの高分子系において大 変形応力緩和測定より得られる緩和弾性率 $G(t, \gamma)$ は式(2)が 成立することが知られている ${ }^{31,33)}$.

$$
G(t, \quad \gamma)=G(t) h(\gamma)
$$

ここで, $G(t)$ および $h(\gamma)$ はそれぞれ線形緩和弾性率および ダンピング関数である. 大変形応力緩和測定の一例として, Fig. 6 に $40{ }^{\circ} \mathrm{C}$ における V-48 および Co2-58 の $30 \%$ 溶液の大 変形応力緩和測定結果を示す。どちらの系も式(2)に示す歪 みー時間分離型が成立した。

Fig. 7 に $40^{\circ} \mathrm{C}$ におけるV-48, Y1-45およびCo2-58の $30 \%$ 溶液の換算緩和弾性率 $G(t, \gamma) h(\gamma)^{-1}$ を示した。長時間 領域における Y1-45 および Co2-58 の換算緩和弾性率曲線の 傾きは，V-48のそれよりも緩やかであり，長い緩和時間機 構の存在が示唆される. 4 種類の $30 \%$ 溶液試料の換算緩和 弾性率を求める際に得られたダンピング関数の歪依存性を Fig. 8 に示した. なお，ここでは Y2-43のダンピング関数は 示していないが，V-48のそれらとほぼ同一であった。図よ

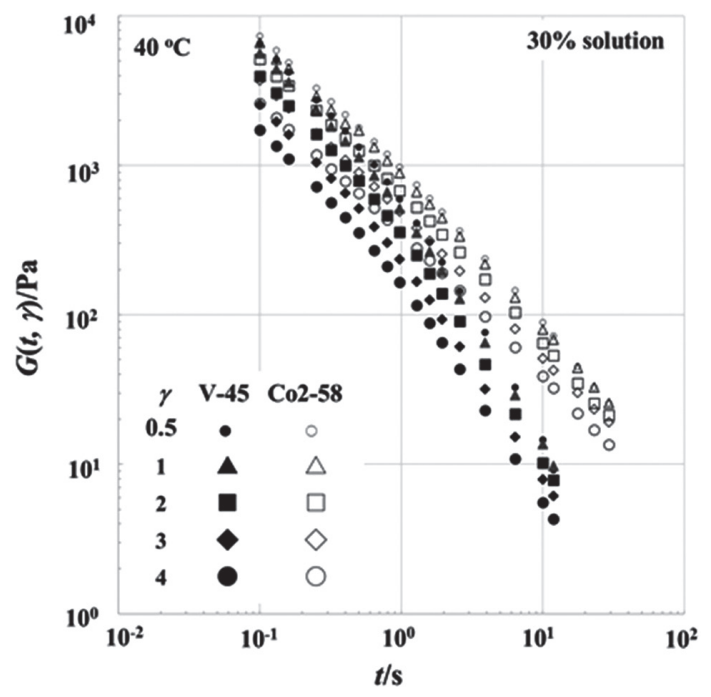

Fig. 6 Relaxation modulus $G(t, \gamma)$ for two $30 \%$ samples of V-48 and Co2-58 at $40{ }^{\circ} \mathrm{C}$ as a function of time $t$ at various strain $\gamma$. 
り，V-48（Y2-43）の測定結果は Doi-Edwards 理論 ${ }^{33)}$ からの 予示曲線とかなり近いことがわかる。一方，Y1-45, Co1-58 およびCo2-58 は理論予示曲線とは明らかに異なり，大きい 值を示すこともわかる。これらより，V-48 およびY2-43は 直鎖構造であり，Y1-45, Co1-58 およびCo2-58 は長鎖分岐 構造である22)ことが示唆される。また，同一ひずみにおけ るダンピング関数の大小から, 長鎖分岐構造の複雑さの序列 は, Y1-45>Co1-58>Co2-58 となり, 前節で示した線形粘弾 性測定からの結果と一致した。

一般的な線形粘弾性および非粘弾性測定から分子量に分布 がある PB の分子構造, 特に長鎖分岐の有無を把握すること ができた。また，二つの測定から長鎖分岐構造の複雑さの序 列が一致することもわかった。 しかし, 本研究で用いた PB の長鎖分岐の数, 長さおよび長鎖分岐鎖における分岐の有無 などの違いを定量的に把握することはできていない．長鎖分 岐構造のさらに詳しい解析については, 最近のレオロジー解 析 ${ }^{26-28)}$ だけではなく, 他の分析手法も取り入れる必要がある と考えられる.

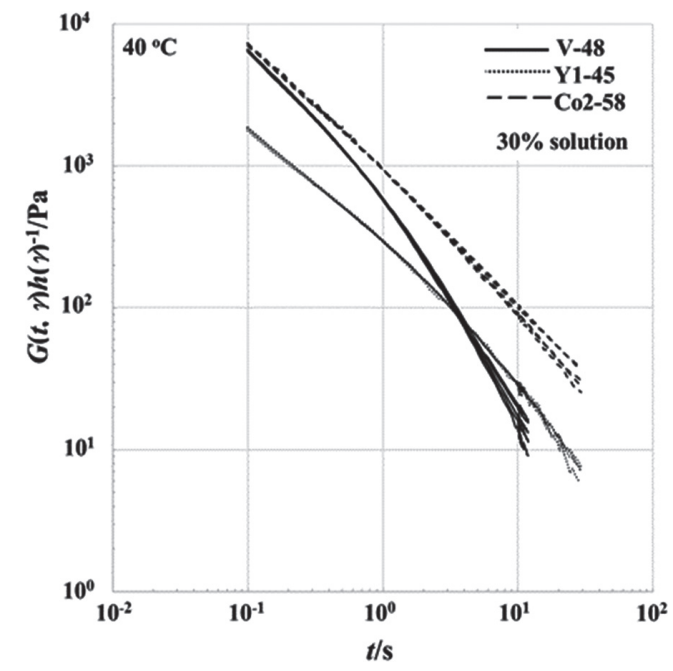

Fig. 7 Reduced plot of relaxation modulus $G(t, \gamma) h(\gamma)^{-1}$ for $30 \%$ PB samples of V-48, Y1-45 and Co2-58 at $40{ }^{\circ} \mathrm{C}$, where $h(\gamma)$ is a damping function.

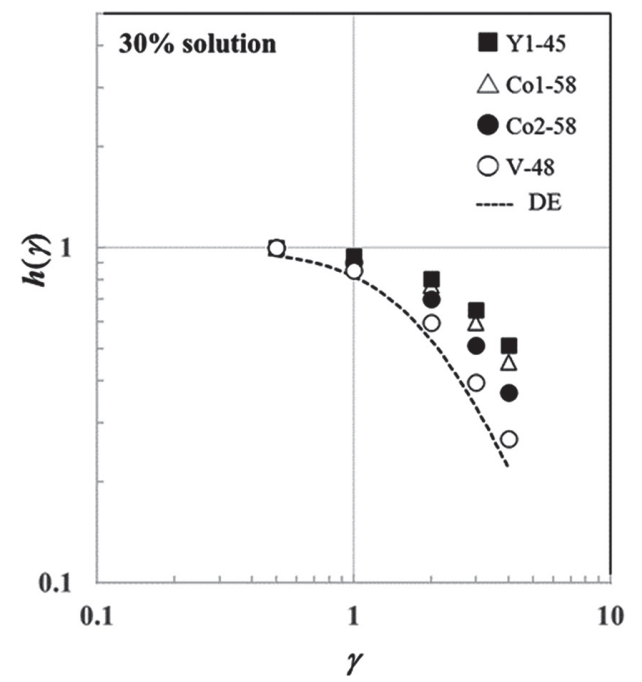

Fig. 8 Strain dependence of damping functions for $30 \%$ PB samples of Y145 , Co1-58, Co2-58 and V-48. The broken line represents the prediction from Doi-Edwards theory.

\section{4. 結 論}

本研究では，3つの異なる触媒と 2 つのプロセスによって 合成された $5 つ の P B$ 系列（Y1，Y2，V，Co1，Co2）の線 形粘弾性および非線形粘弾性特性を測定して, それらの分子 構造，特に長分岐構造の違いを調べた。

流動パラフィンを溶媒として PB 濃厚溶液 $(10 \sim 100 \%)$ を調製し, 濃度 $(c)$ で補正した $G^{\prime} c^{-2}$ と $G^{\prime \prime} c^{-2}$ の関係は PB 分 子内に存在する長鎖分岐の有無に強く依存した。長鎖分岐構 造を持つ $\mathrm{PB} の G^{\prime \prime} c^{-2}=20,000 \mathrm{~Pa}$ における $G^{\prime} c^{-2}$ の值は, $\mathrm{PB}$ 濃度とともに増加するだけでなく，長鎖分岐構造の差異に応 じて増加する。一方, 直鎖構造の $G^{\prime} c^{-2}$ の值は濃度に依存し ない。これらの結果から, 複雑な長分岐構造の順序は $\mathrm{Y} 1>\mathrm{Co} 1>\mathrm{Co} 2>\mathrm{V} \approx \mathrm{Y} 2$ となった。 また， $30 \% \mathrm{~PB}$ 溶液の大 変形応力緩和測定によって評価したダンピング関数から, 複 雑な長分岐構造の序列は $\mathrm{Y} 1>\mathrm{Co} 1>\mathrm{Co} 2>\mathrm{V} \approx \mathrm{Y} 2$ となった. 二つの測定から長鎖分岐構造の複雑さの序列は一致すること がわかった．本研究で提案したレオロジー手法により分子量 分布を有する PB の長鎖分岐構造の違いを定性的ではあるが 把握できる。

\section{謝 辞}

本研究の発表を許可して頂いた宇部興産株式会社に感謝致 します。

\section{REFERENCES}

1) Yamashita S, Nihon Gomu Kyoukaishi, 36, 883 (1963).

2) Iino H, Tsukasa M, Nagafune T, Minoura Y, Nihon Gomu Kyoukaishi, 35, 404 (1962).

3) Editorial Board, Nihon Gomu Kyoukaishi, 84, 384 (2011).

4) Editorial Board, Nihon Gomu Kyoukaishi, 84, 387 (2011).

5) Nuyken O, "Neodymium Based Ziegler CatalystsFundamental Chemistry”, Adv Polym Sci, 204, (2006), Springer-Verlag Berlin Heidelberg.

6) Kaita S, Koubunshi, 55, 266 (2006).

7) Annunziata L, Pragliola S, Pappalardo D, Tedesco C, Pellecchia C, Macromolecules , 44, 1934 (2011).

8) Robert D, Abinet E, Spaniol TP, Okuda J, Chem, Eur J, 15, 11937 (2009).

9) Sone T, Nihon Gomu Kyoukaishi, 88, 178 (2015).

10) Shiba K, Murakami M, Suzuki M, Okamoto N, Anbe M, Tanaka M, JP Patent 6390610.

11) Shiba K, Yamada Y, Fukazawa S, Okamoto N, JP Patent 6665779.

12) Homma T, Koubunshi, 31, 1075 (1982).

13) Uraneck CA, Short JN, J Appl Polym Sci, 14, 1421 (1970).

14) Ozawa Y, Koubunshi, 54, 750 (2005).

15) Matsuda T, Nihon Gomu Kyoukaishi, 78, 46 (2005).

16) Norisue T, Nakamura Y, Koubunshi, 47, 816 (1998).

17) Trackx P, Tacx JCJF, Polymer, 39, 3109 (1998).

18) Yan D, Wang WJ, Zhu S, Polymer, 40, 1737 (1999).

19) Raju VR, Rachapudy H, Graessley WW, J Polyme Sci Polym Phys Ed, 17. 1223 (1979). 
20) Lohse DJ, Milner ST, Fetters LJ, Xenidou M, Hadjichristidis $\mathrm{N}$, Mendelson RA, Garcia-Franco CA, Lyon MK, Macromolecules, 35, 3066 (2002).

21) Yamaguchi M, Takahashi M, Polymer, 42, 8663 (2001).

22) Osaki K, Rheol Acta, 32, 429 (1993).

23) Larson RG, $J$ Rheol, 28, 545 (1984).

24) Wagner MH, Yamaguchi M, Takahashi M, J Rheol, 47, 779 (2003).

25) Wagner MH, Hepperle J, Münstedt H, J Rheol, 48, 489 (2004).

26) McLeish TCB, Allgaier J, Bick DK, Bishko G, Biswas P, Blackwell R, Blottière B, Clarke N, Gibbs B, Groves DJ, Hakiki A, Heena RK, Johnson JM, Kant R, Read DJ, Young
RN, Macromolecules, 32, 6734 (1999).

27) Daniel DR, McLeish TCB, Crosby BJ, Young RN, Fernyhough CM, Macromolecules, 34, 7205 (2001).

28) Van Gurp M, Palmen J, Rheol Bull, 67, 5 (1998).

29) Sone T, Nihon Gomu Kyoukaishi, 80, 208 (2007).

30) Murakami M, Shiba K, Shoda T, Anbe M, JP Patent 5776819.

31) Ferry JD, "Viscoelastic Properties of Polymers", $3^{\text {rd }}$ ed, (1980), John Wiley \& Sons Inc, New York.

32) Han CD, Kim J, J Polym Sci B, 25, 1741 (1987).

33) Doi M, Edwards SF, "The Theory of Polymer Dynamics", (1986), Clarendon, Oxford. 